NBER WORKING PAPER SERIES

DO POLITICAL INSTITUTIONS SHAPE ECONOMIC POLICY?

Torsten Persson

Working Paper 8214

http://www.nber.org/papers/w8214

\author{
NATIONAL BUREAU OF ECONOMIC RESEARCH \\ 1050 Massachusetts Avenue \\ Cambridge, MA 02138 \\ April 2001
}

This paper is based on my Walras-Bowley lecture given at the Eighth Word Congress of the Econometric Society, in Seattle August 2000. I am heavily indebted to Guido Tabellini, who is a co-author of all the work underlying this leture and provided detailed comments on a previous draft. I would also like to thank John Moore for comments, Givanni Favara for research assistance and Christina L"onnblad for editorial assistance. The research is supported by grants from the European Commission and the Swedish Council for Research in the Humanities and Social Sciences. The views expressed herein are those of the author and not necessarily those of the National Bureau of Economic Research.

(C) 2001 by Torsten Persson. All rights reserved. Short sections of text, not to exceed two paragraphs, may be quoted without explicit permission provided that full credit, including (C) notice, is given to the source. 
Do Political Institutions Shape Economic Policy?

Torsten Persson

NBER Working Paper No. 8214

April 2001

JEL No. D7, E6, H1

\begin{abstract}
$\underline{\text { ABSTRACT }}$
Do political institutions shape economic policy? I argue that this question should naturally appeal to economists. Moreover, the answer is in the affirmative, both in theory and in practice. In particular, recent theoretical work predicts systematic eects of electoral rules and political regimes on the size and composition of government spending. And results from ongoing empirical work indicate that such eect are indeed present in international panel data. Some empirical results are consistent with theoretical predictions: presidential regimes have smaller governments and countries with majoritarian elections have smaller welfare-state programs and less corruption. Other results present puzzles for future research: the adjustment to economic events is clearly institutiondependent, as is the timing and nature of the electoral cycle.
\end{abstract}

Torsten Persson

IIES, Stockholm University

LSE, CEPR, and NBER

torsten.persson@iies.su.se 


\section{Initial remarks}

In the last five to ten years, political economy - or "political economics", as I prefer to call it - has been a rapidly growing field. As the label suggests, this field deals with issues related to politics using the tools of modern economics. The most recent work is attractive in that it draws on several traditions: the older public-choice school, the rational-choice school in political science, and the equilibrium theory of macroeconomic policy. Collected works, monographs and textbooks now start to appear, drawing on the contributions in the last decade. One such piece is Persson and Tabellini (2000a), others include Mueller (1997), Austen-Smith and Banks (1999), Drazen (2000), and Grossman and Helpman (2000).

An obvious motivation for this literature comes from observing economic policy outcomes. Looking across time and place, one observes large differences in policy, but also some common patterns. An example is given in Figure 1, which shows a measure of the size of government in about sixty countries over the last four decades. In the figure we see that government expenditure in a typical year ranges from below 10 percent of GDP to well above 50 percent. We also see how the distribution drifts upwards over time, reflecting growth in the average size of government - the curve in the graph - by about 8 percent of GDP from the 1960s to the mid 1990s. (I will discuss these data further in Section 3.) Such differences and similarities cry out for an explanation. An important goal in the literature has thus been to construct a positive theory of economic policy.

This brings me to the subject-matter of my lecture, which I will devote to current research on largely unresolved issues. As the title suggests, I will focus on attempts to identify what systematic effect political institutions might have on economic policy outcomes. This is, of course, a very broad question. ${ }^{1}$ To narrow it down, I will confine the discussion to the institutions governing electoral rules and political regimes and their effect on fiscal policy, broadly defined. This question is not only of academic interest. For instance, reform of electoral institutions has recently taken place in Japan, Italy and New Zealand and is a hotly debated issue in other countries. Theory and evidence on the policy consequences of alternative electoral rules would enlighten this debate.

\footnotetext{
${ }^{1}$ Other work by economists on the broad question includes the literatures on the links between budgetary institutions and budget deficits (see, for instance, the contributions in Poterba and von Hagen, 1999) and between fiscal federalism and the size of government (surveyed by Inman and Rubinfeld, 1997); see Persson and Tabellini (2000a) for further references.
} 
I would like to make two main points. First, the question whether political institutions shape policy should naturally appeal to an economist. Second, the answer is yes; empirically, electoral rules and political regimes do seem to systematically influence the choice of fiscal instruments, as well as the incidence of corruption.

Next, I will outline the main ideas in a recent wave of theoretical work on the topic of the lecture (Section 2). Then, I will describe some data we have just assembled, with the aforementioned theory as the main guide in sampling and measurement (Section 3). A good part of my lecture will report on two ongoing empirical projects, dealing with the link from political institutions to fiscal policy and corruption (Section 4). Finally, I will sum up and discuss where research might go next (Section 5).

\section{Theoretical ideas}

\subsection{A n organizing framework}

Let me describe the theoretical ideas against the backdrop of a very simple model. In particular, let us consider a bare-bones model of fiscal policy which highlights the size of the government budget and its allocation to different purposes. ${ }^{2}$

The population is divided into a large number of groups, labeled by $J$. Membership of each group is defined by the prospective benefits of public spending. Everybody has the same preferences over policy:

$$
\begin{aligned}
w^{\jmath} & =U\left(c^{\jmath}\right)+H(g) \\
c^{\jmath} & =y-\tau+f^{\jmath} .
\end{aligned}
$$

Group $J$ has size $N^{J}$. Its members thus enjoy private consumption, $c^{J}$, given by after-tax income plus a group-specific transfer $f^{\jmath}$. All groups pay the same tax, $\tau$, and enjoy the same benefits of public spending on $g$. Government spending can thus be targeted to specific groups, as in the case of targeted transfer programs, or local public goods. But it can also take a non-targeted form benefiting all citizens, as in the case of general public goods, or broad social programs.

Policy choices are summarized by $\mathbf{q}$, a vector constrained to include nonnegative elements only:

$$
\mathbf{q}=\left[\left\{f^{\jmath}\right\}, g, \tau, r\right] \geq 0
$$

\footnotetext{
${ }^{2}$ The core of the positive models of fiscal policy in Persson and Tabellini (2000a) is similar.
} 


$$
r=N \tau-g-{ }^{\mathrm{X}} N^{\jmath} f^{\jmath} .
$$

The budget constraint is standard except for one item. The variable $r$ does not appear directly in the citizens' payoffs. Literally, it represents direct extraction of rents by politicians for private use. Less literally, it may represent - on reduced form - corrupt activities, or inefficiently designed activities that constitute a drain for the citizens but benefit politicians or their close friends.

This model is obviously very stylized. Richer economic models can certainly be studied along the same lines. Citizens would then also interact in markets, making purposeful economic choices influenced by policy. Similarly, we could replace the simplistic form of rent extraction with a structural model.

Yet, already the bare-bones model permits a rich analysis of the politics of policymaking. To see this, note that the choice of $\mathbf{q}$ generates conflicts of interest in three different dimensions: (i) First, we have the traditional conflict among different groups of voters over the allocation of targeted spending $\left\{f^{\jmath}\right\}$. (ii) The second is an agency problem: the voters at large would like higher $g$ or lower $\tau$, but rent-seeking politicians would instead like to spend these resources on $r$. (iii) A final source of conflict is that different politicians, or political parties, will compete for any available rents.

\subsection{General ideas}

The basic idea in the recent literature is this: The way the three conflicts are resolved, and thus what fiscal policy we observe, hinges on the political institutions in place. This idea should appear very natural to an economist. Consider an analogy from micro theory. In a market, we have conflicts of interest between consumers and producers over price and product quality, and among different producers over profit. How these are resolved depends on market institutions. Equilibrium prices, qualities and profits hinge on regulation, which determines the barriers to entry and the scope for competition between producers. They also hinge on legislation, which determines how easily consumers can hold producers accountable for bad product quality or collusive pricing behavior. The basic idea here is the same.

Political institutions certainly have many dimensions. Arguably, however, the most fundamental aspects of constitutions decide how the "control rights" over policy are acquired and how they can be exercised. Thus, which politicians get the power to make policy decisions is determined by voters, but is crucially influenced 
by rules for elections. Policy choices are made by elected politicians, but are crucially influenced by rules for rule-making and legislation; that is, what political scientists call the regime type.

While economists have not paid much attention to the consequences of these institutions, political scientists certainly have. A large, mostly empirical literature has focused precisely on electoral rules and regime types. But the analysis has generally been confined to purely political phenomena, such as the number of parties, the propensity for crises, etc. It has ignored economic policy, our topic here. $^{3}$

This general discussion suggests a way of modeling the outcome of policymaking: $\mathbf{q}$ in our simple model. In that approach, policy is the equilibrium outcome of a delegation game, where the interaction between rational voters and politicians is modeled on extensive form. Multiple principals, the voters, elect political representatives who, in turn, set policy to further their own opportunistic objectives. The principals have some leeway over their agents because they can offer them election, or re-election. But these rewards are mostly implicit, not explicit, so the constitution becomes like an incomplete contract, leaving the politicians with some power in the form of residual control rights. Alternative constitutions can now be represented by alternative rules for how this extensive-form game is being played. An exercise in "comparative politics" amounts to comparing the policy outcomes across the resulting equilibria.

\subsection{Specific predictions}

Let me now describe the main ideas in a handful of recent studies that apply this comparative politics approach. I just outline the results, however, focusing on the specific predictions. Those interested can find most of the analytical details in Persson and Tabellini (2000a, Part III).

E lectoral rules. I begin with the rules for electing a country's legislature. Legislative elections around the world differ in several dimensions. The political science literature emphasizes two: district size and the electoral formula. District size simply determines how many legislators acquire a seat in a voting district.

\footnotetext{
${ }^{3}$ An exception is a recent book by Lijphart (1999), which includes cursory evidence on economic policy outcomes. Modern classics within the political science literature on comparative politics include Bingham Powell (1982), Lijphart (1984), Taagepera and Shugart (1989), Shugart and Carey (1992), and Cox (1997); see Myerson (1999) for a discussion of the theoretical literature on the consequences of different electoral rules.
} 
The electoral formula determines how votes are translated into seats. Under plurality rule, only the winners of the highest vote shares get seats in a given district, whereas proportional representation instead awards seats in proportion to the vote share.

Anticipating already here the empirical part, we find a strong correlation in these features across real-world electoral systems. Some systems can be described as majoritarian, combining small voting districts with plurality rule. Archetypes here are elections to the UK parliament or the US Congress, where whoever collects the most votes in a district gets the single seat. Some electoral systems are instead decidedly proportional, combining large electoral districts with proportional representation. Archetypes are the Dutch and Israeli elections, where parties obtain seats in proportion to their vote shares in a single national voting district. While we find some intermediate systems, most countries fall quite unambiguously into this crude classification.

Why would district size matter for government spending? One idea is that larger voting districts diffuse electoral competition, inducing parties to seek support from broad coalitions in the population. Smaller districts steer electoral competition towards narrower, geographical constituencies. Clearly, broad programs, like $g$ in the model above, are more effective in seeking broad support and targeted programs, like $f^{\jmath}$, more effective in seeking narrow support. Proportional elections with larger districts should thus be more biased towards broad, non-targeted programs. This point has formally been made by Persson and Tabellini (1999) in a probabilistic-voting model, where policy is determined by electoral platforms before the election. Milesi-Ferretti, Perotti and Rostagno (2000) obtain a similar result in a model of strategic delegation in voting, where policy is set after the election in bargaining among the elected politicians.

Larger districts also facilitate entry in the political process by additional candidates or parties. Myerson (1993) has used a model of electoral competition to show how a larger number of candidates under proportional elections may produce lower equilibrium rents. Essentially, with more available candidates, voters can throw out corrupt parties at a lower ideological cost.

How about the electoral formula? The winner-takes-all property of plurality rule reduces the minimal coalition of voters needed to win the election, as votes for a party not obtaining plurality are lost. With single-member districts and plurality, a party thus needs only $25 \%$ of the national vote to win: $50 \%$ in $50 \%$ of the districts. Under full proportional representation it needs $50 \%$ of the national vote. Politicians are thus induced to internalize the policy benefits for a larger 
segment of the population, which reinforces the previous prediction associating broader spending programs with proportional elections. Lizzeri and Persico (2000) make this point in a model with binding electoral promises, while Persson and Tabellini (2000a, Ch. 9) instead consider policy choices by an incumbent subject to re-election.

Under majoritarian elections, electoral competition often becomes concentrated to a subset of identifiable "marginal districts". As these have close races with many swing voters, the perceived electoral punishments for inefficient programs become larger. The smaller expected vote losses under proportional elections induce candidates involved in electoral competition to chooses policies entailing larger rents ( $r$ in the model), a result derived in Persson and Tabellini, 1999.

While voters cast their ballot among individual candidates under plurality rule, they cast it among party lists under proportional representation. Such lists may dilute the incentives for individual incumbents to perform well. Persson and Tabellini (2000a, Ch. 9) examine the policy consequences of this difference in a model where individual politicians have career-concerns in the style of Holmström (1982). They find that proportional representation (list voting) should be associated with a larger extraction of rents, as the career-concern, re-election motive becomes a weaker counterweight to the rent-extraction motive for collectively accountable politicians. A second prediction is that electoral cycles, showing up in spending or taxes, should be weaker under proportional representation. This is because the incumbents' career concerns are stronger with the individual accountability under plurality rule and because these concerns are at their strongest just before elections.

Regime types. Two especially interesting aspects of the legislative regime concern the powers over legislation: to make, amend, or veto policy proposals. The first concerns the separation of these powers across different politicians and offices. The second concerns the maintenance of these powers; in particular, whether the executive needs sustained confidence by a majority in the legislative assembly.

As in the case of electoral rules, we can make a cruder classification of realworld regimes. Presidential regimes (abbreviated PRES) typically have separation of powers, between the president and Congress, but also between congressional committees that hold important proposal (agenda-setting) powers in different spheres of policy (think about the US). But they do not have a confidence requirement: the executive can hold on to his powers without the support of a 
majority in Congress. In parliamentary regimes ( $P A R L)$, the proposal powers over legislation are instead concentrated in the hands of the government. Moreover, the government needs the continuous confidence of a majority in parliament to maintain those powers throughout an entire election period.

Why should separation of powers matter for policy? A classical argument is that checks and balances constrain politicians from abusing their powers. Persson, Roland, and Tabellini $(1997,2000)$ formally demonstrate this old point in models where incumbents, who decide on policy in different forms of legislative bargaining, are held accountable by retrospective voters. They show that a larger concentration of powers in parliamentary regimes makes it easier for politicians to collude with each other at the voters' expense; the weaker electoral accountability results in higher rents and taxes ( $r$ and $\tau$ in the model ).

Another idea has to do with the confidence requirement. The parties supporting the executive hold valuable proposal powers which they risk to lose in a government crisis. Therefore, they have strong incentives to maintain a stable majority when voting on policy proposals in the legislature. Building on this idea of "legislative cohesion" due to Diermeier and Feddersen (1998), Persson, Roland and Tabellini (2000) derive two additional predictions. First, in parliamentary regimes, a stable majority of legislators tends to pursue the joint interest of its voters. In presidential regimes, the (relative) lack of such a majority instead tends to pit the interests of different minorities against each other for different issues on the legislative agenda. Equilibrium spending in parliamentary regimes thus becomes more directed towards broad programs $\left(g\right.$ rather than $\left.f^{\jmath}\right)$. Second, in parliamentary regimes, the stable majority of incumbent legislators, as well as the majority of the voters backing them, become prospective residual claimants on additional revenue. Both majorities favor high taxes and high spending. In presidential regimes, on the other hand, no such residual claimants on revenue exist and majorities therefore resist high spending. These forces produce larger governments (higher $\tau$ ) in parliamentary regimes.

\subsection{Discussion}

Let me summarize the main predictions with the help of Table 1. According to the theory, presidential regimes should have smaller governments than parliamentary regimes, less spending on broad programs, and less rents for politicians. Under majoritarian elections, we should see less spending on broad programs than under proportional elections, and less rents. These are "cross-sectional" predictions; 
they have been derived by comparing equilibria in static models. The prediction of more pronounced electoral cycles under majoritarian elections, however, relies on a dynamic model and is thus a "time-series" prediction.

Is this kind of analysis convincing? Some of you may be skeptical. One critique might question whether the simple assumed game forms capture the essence of real-world political institutions. This would parallel the critique against theoretical IO that "you could prove anything by picking the right extensive form and the right informational assumptions". A related complaint would parallel the critique against incomplete-contract theory that "there are many alternative assignments of control rights and you have no strong basis for choosing this particular one".

Such criticism has some force, but may be less damaging in this case, as long as we deal with positive theory rather than normative "constitutional engineering". A wealth of historical, political and legal studies document how the world's democracies carry out elections and allocate political and legislative control. Thus, the rules defining a particular game need not rely on the researcher's imagination. They can and should be given a solid empirical foundation. From this perspective, comparative politics might offer a more convincing application of game theory than other examples in economics.

Defending the underlying assumptions is not the only way of convincing skeptics, however. Another criterion of success is the empirical contents of the theory. Does it help us uncover new empirical regularities? To shed some light on this question, I now turn to the empirical part of the lecture.

\section{Data and specification}

Data. Let me start by briefly describing the data on political institutions and fiscal policy outcomes we have assembled for ongoing empirical research. More details can be found in Persson and Tabellini (2000b). In fact, the theory I just sketched has served as our guide in sampling and measurement. We have data for at most 61 countries. The data is yearly and runs from 1960 to 1998, a total of 39 years. This panel includes a large number of economic, social and political variables. But many observations are missing - for different reasons - which makes the panel unbalanced.

Which countries are included in the panel? The theory suggest we should study countries with democratic institutions. To assess a country's democratic status in a given year, we rely on the well-known Freedom House indexes of political rights: the so-called GASTIL-indexes. We have used three selection rules. One is 
to include a country in the sample from the first year when it reaches a GASTILscore of less than or equal to 5, signifying that the country is "free", or "semifree". 4 Two more demanding rules for inclusion in the sample are to require a score strictly less than or equal to 3.5 or 2, respectively, and to apply these cutoffs year by year. Unfortunately, non-availability of data on political institutions or fiscal policy cuts down the sample size further. Here, I will only present results based on the mid-way sampling rule (a GASTIL-score less than or equal 3.5, year by year). As the more comprehensive analysis in Persson and Tabellini (2000b) demonstrates, most results are similar in the two alternative sets of democracies.

Which political institutions do we study? Following the theory discussion in Section 2, I will report on results which are (mostly) based on two crude classifications of electoral rules and regime types. First, we code countries that relied fully on plurality (or majority) rule in their most recent elections to the legislature (lower chamber) as majoritarian, and the other countries as proportional. The dummy variable $M A J$ takes a value of 1 in the former case, 0 in the latter. ${ }^{5}$ Second, countries where the survival of the executive does not require the confidence of the legislature are coded as presidential, the other countries as parliamentary. The resulting binary variable is called PRES.

These classifications change very little over time, reflecting an inertia of political institutions sometimes called an "iron law" by political scientists. The lack of time variation is unfortunate in that it provides us with almost no "experiments" in the form of regime changes. But it is also an indication that our key maintained assumption, namely to treat institutions as exogenous and given by history, may be correct.

Figure 2 illustrates the institutional variation across countries in 1995. The colored portions of the map represent the countries in the sample. Striped areas indicate presidential regimes $(P R E S=1)$, solid areas parliamentary regimes $(P R E S=0)$. Darker shade indicates majoritarian elections $(M A J=1)$, lighter shade proportional elections $(M A J=0)$. The least common system is the USstyle (dark-striped) combination of a presidential regime with majoritarian elections, with only five countries. But each of the other three combinations is well represented in the sample. As the map illustrates, using theory in the classifi-

\footnotetext{
${ }^{4}$ There are actually two indexes, one on political rights one on civil liberties. Each index runs from 1 to 7 , where a country with scores of 1 or 2 are "free", 3 to 5 "semi-free", and 6 to 7 "not free". We take the simple average of these indexes.

${ }^{5}$ In Persson and Tabellini (1999) electoral rules were instead classified on the basis of district magnitude. The present classification based on the electoral formula yields a similar, but not identical grouping of countries.
} 
cation sometimes produces results contrary to popular perception. For example, Switzerland is classified as a presidential regime, whereas France is not.

We include fiscal policy outcomes suggested by the theory. For the size of government (corresponding to $\tau$ in the model) we use different measures: central government expenditure, central government revenue, and general government expenditure, all as percentages of GDP. For the composition of government spending ( $g$ vs. $\left\{f^{\jmath}\right\}$ in the model) we use two measures: social security and welfare spending (by central government), either as a percentage of GDP, or as a ratio to spending on goods and services. We thus presume that it is much harder to target broad transfer programs, like pensions and unemployment insurance, to specific voting districts than it is to target spending on goods and services. These various fiscal policy measures do vary greatly across time and across countries. Indeed, Figure 1 in the introduction was a plot of our panel data for central government expenditure as a percentage of GDP.

At the end of the next section, I will also describe some results from a second ongoing project (Persson, Tabellini, and Trebbi, 2000). There, we proxy rent extraction by politicians ( $r$ in the model) by available measures of corruption. We also characterize electoral rules by two continuous measures, rather than by a single binary measure.

Specification. Our empirical work is certainly motivated by theory. In addition to testing specific hypotheses, we also aim at establishing empirical regularities, however. We therefore adopt a relatively eclectic empirical specification describing policy outcomes:

$$
y_{\mathrm{it}}=\alpha_{\mathrm{i}}+\boldsymbol{\beta}_{\mathrm{i}} \mathrm{u}_{\mathrm{t}}+\boldsymbol{\gamma}_{\mathrm{i}} \mathrm{s}_{\mathrm{it}}+\boldsymbol{\delta} \mathbf{x}_{\mathrm{it}}+\boldsymbol{\eta} \mathbf{z}_{\mathrm{it}}+\varepsilon_{\mathrm{it}} .
$$

Here, $y_{\text {it }}$ denotes a policy outcome in country $i$ and year $t$. We allow for a countryspecific component, $\alpha_{i}$. Policy can be affected directly by the institutions $\mathbf{z}_{\mathrm{it}}$, concretely by the value of the two dummy variables MAJ and PRES in $i$ at $t$. It also depends on (vectors of) common variables $u_{t}$ and idiosyncratic variables $\left(S_{i t}, X_{i t}\right)$. Some slope coefficients are allowed to differ across countries.

Given (1), we pose the question of a systematic effect from institutions to policy in two different ways. One is to test the nul hypothesis

$$
H_{0}^{\mathrm{D}}: \boldsymbol{\eta}=0,
$$

i.e., the absence of a direct effect. Strictly speaking, this is what most of the theory discussed in Section 2 was really about. The other way is to test for the 
absence of an indirect (non-linear) effect

$$
H_{0}^{l}: \boldsymbol{\beta}_{\mathrm{i}}=\boldsymbol{\beta}_{\mathrm{j}} \text { and } / \text { or } \boldsymbol{\gamma}_{\mathrm{i}}=\boldsymbol{\gamma}_{\mathrm{j}} \text {, even if } \mathbf{z}_{\mathrm{it}} \neq \mathbf{z}_{\mathrm{jt}},
$$

i.e., whether different institutions make policy respond to common or idiosyncratic variables in a different way. (The rationale for this test will be given shortly.) We estimate these parameters in several different fashions, which are probably best explained in the context of a specific example.

\section{Empirical regularities?}

\subsection{Size of government}

Cross-sectional results. Consider first the size of government. To arrive at a straightforward test for a direct effect on policy, take the time average of (1) to obtain

$$
\bar{y}_{\mathrm{i}}=\left(\alpha_{\mathrm{i}}+\boldsymbol{\beta}_{\mathrm{i}} \mathrm{u}+\boldsymbol{\gamma}_{\mathrm{i}} \overline{\mathrm{S}}_{\mathrm{i}}\right)+\boldsymbol{\delta} \mathrm{x}_{\mathrm{i}}+\boldsymbol{\eta} \mathbf{z}_{\mathrm{i}}+\bar{\varepsilon}_{\mathrm{i}} .
$$

As (2) shows, the $\eta$ parameter can be readily estimated on cross-sectional data. To take account of the unbalanced panel, we use a WLS estimator weighing each country by the number observations in its panel.

Results from such regressions are displayed in Table 2. The dependent variable is either central government spending (as a percentage of GDP), or central government revenue. The control variables in $\mathbf{x}_{1}$ include a number of socio-economic factors identified by earlier studies as empirical determinants of the size of government. Given the clustering of observations in Figure 2, we use dummies for continents and colonial origin as additional controls. The table displays the estimated $\eta$ parameters for the PRES and MAJ dummies. Bracketed expressions are $p$-values for false rejection of $\boldsymbol{\eta}=0$. Boldface font denotes a coefficient significantly different from zero, at the $10 \%$ level.

The two institutional dummies always enter with a negative sign. But $M A J$ is rarely statistically significant. ${ }^{6}$ On the other hand PRES typically is, even though one can find specifications where it is not. This finding is clearly in line

\footnotetext{
${ }^{6}$ Milesi-Ferretti, Perotti and Rostagno (2000) find government expenditure to be smaller in countries with majoritarian elections in their study of the OECD countries over the same period. When we use general government expenditures as our dependent variable - as did Milesi-Feretti et al. - we reach a similar conclusion. In this case data availability cuts down our sample size considerably (to about 40 countries).
} 
with the theoretical prediction in Section 2. According to the point estimates, governments in presidential regimes are smaller by more than 5 percent of GDP.

As column 3 shows, however, the negative effect of PRES is stronger, above 10 percent of GDP, for cross sections based on data from the 1990s rather than the whole sample. Moreover, it is statistically more robust (cf. also the empirical results in Persson and Tabellini, 1999). These results suggest that the negative estimates largely reflect faster growth of government in parliamentary regimes in the last four decades. As Figure 3 illustrates, this pattern is clearly visible already in the raw data. The graph is identical to Figure 1, except that the data is partitioned into presidential regimes, marked with black diamonds and a thicker curve for the average, and parliamentary regimes, marked with circles and a thinner curve.

While these cross-sectional estimates are suggestive, they are potentially subject to simultaneity (omitted-variable, selection) bias. We would therefore like to exploit the time variation in the data. But the lack of institutional variation over time makes it infeasible to identify the direct effect of institutions in conventional fixed-effects estimation. For practical purposes, $z_{i t}$ is given by a constant, $\mathbf{z}_{\mathbf{i}}$, equal to the time average $\mathbf{z}_{\mathbf{i}}$. Thus, we cannot separately estimate the effects on policy of a country's institutions $\mathbf{z}_{\mathbf{i}}$ and other time-invariant, country-specific features $\alpha_{\mathrm{i}}$.

This is why we turn to the slightly different question embodied in the test of $H_{0}^{1}$, namely whether different political institutions shape different policy responses to economic and political events. Even if the cross-section results might possibly be biased due to "historical omitted variables", it is less plausible to argue that the forces selecting the observed political institutions in historical times would be systematically correlated with the response to economic and political events during our recent sample period.

Recall, however, that the models in Section 2 are all static, with the exception of the career-concern model of electoral cycles. Many of our tests for indirect effects of institutions should thus be seen as a search for empirical regularities rather than tests of specific predictions.

U nobservable common events It is plausible that a set of common economic and political events have affected fiscal policy in all countries. Think e.g. of the worldwide turn to the left in the late 1960s and 70s, or the productivity slowdown and oil shocks in the 1970s and 80s. But suppose we do not want to commit to, or cannot observe, all such events. Blanchard and Wolfers (2000) suggest a 
simple statistical method which they use to estimate how labor-market institutions might influence the adjustment of unemployment to unobservable shocks. MilesiFerretti, Perotti and Rostagno (2000) indeed apply this method to study how the proportionality of electoral systems affect policy in the OECD countries.

Assume that the response to observable idiosyncratic variables is the same in all countries, $\gamma_{\mathrm{i}}=\gamma_{\mathrm{j}}$ in (1). Then we can lump all country-specific variables together in $\mathrm{X}_{\mathrm{it}}$ and rewrite (1) as:

$$
y_{i t}=\left(\alpha_{i}+\boldsymbol{\eta} \mathbf{z}_{\mathrm{i}}\right)+\left[1+\boldsymbol{\lambda}\left(\mathbf{z}_{\mathrm{i}}-\mathbf{z}\right)\right] \boldsymbol{\beta} \mathrm{u}_{\mathrm{t}}+\boldsymbol{\delta} \mathbf{x}_{\mathrm{it}}+\varepsilon_{\mathrm{it}} .
$$

We can use a set of time dummies to estimate, $\boldsymbol{\beta} \mathbf{u}_{\mathrm{t}}$, the common effect of the common events in (3). The institution-specific effect of the common events $u_{t}$ is proportional to the term $\boldsymbol{\lambda}\left(\mathbf{z}_{\mathbf{i}}-\mathbf{z}\right)$, where $\mathbf{Z}$ denotes the cross-country average of $\boldsymbol{z}_{\mathbf{i}}$. The form of (3) suggests that we should estimate the crucial parameter $\boldsymbol{\lambda}$ by NLS, and include fixed effects to control for the country-specific intercept.

Table 3 shows some results based on annual data. (Persson and Tabellini, $2000 \mathrm{~b}$ also report results based on five-year averages, which may better handle measurement error and allow for discretionary adjustments of policy.) The country-specific controls are the same variables as in the cross-sectional regressions. The interaction parmeters $\boldsymbol{\lambda}$ for both PRES and MAJ are negative and highly significant. To interpret the results, consider a common event in period $t$ that raises government spending by 1 percent of GDP in an average country; i.e., an event such that $\boldsymbol{\beta}\left(\mathrm{u}_{\mathrm{t}}-\mathrm{u}_{\mathrm{t}-1}\right)=1$. Coefficients around -1 and -0.5 mean that the effect of this event is 1 percent smaller in presidential (compared to parliamentary) regimes and 0.5 percent smaller under majoritarian (compared to proportional) elections.

Another way of gauging the results is to ask how the cumulative effect of the common events over the course of the sample period, $\boldsymbol{\beta}\left(\mathbf{u}_{\mathrm{T}}-\mathrm{u}_{1}\right)$, differs across institutions. The point estimates suggest that the cumulative difference between presidential and parliamentary regimes is above 10 percent of GDP. This number fits well with the estimated cross-sectional difference from the 1990s reported in Table 2. Thus, we can attribute much of the current size difference between these regimes to a different adjustement to a set of common shocks in the preceding decades.

Observable economic events Alternatively, we can test for an effect of institutions on the adjustment to observable events. We start by economic events, 
then turn to electoral events. Yet another rewrite of (1) is given by the following expression:

$$
y_{i t}=\left(\alpha_{i}+\boldsymbol{\eta} \mathbf{z}_{\mathrm{i}}\right)+\left(\boldsymbol{\beta}+\boldsymbol{\phi} \mathrm{z}_{\mathrm{i}}\right) \mathrm{u}_{\mathrm{t}}+\left(\boldsymbol{\gamma}+\boldsymbol{\mu} \mathbf{z}_{\mathrm{i}}\right) \mathrm{s}_{\mathrm{it}}+\boldsymbol{\delta} \mathrm{x}_{\mathrm{it}}+\varepsilon_{\mathrm{it}}
$$

In (4) the parameters $\boldsymbol{\phi}$ and $\boldsymbol{\mu}$ allow for institution-dependent adjustments to common and idiosyncratic variables. As an observable common variable in $u_{t}$ we have tried the oil price, and as idiosyncratic variables in $S_{i t}$ we have included lagged policy $y_{\text {it }-1}$, the share of the population above 65 , and the deviation of income from its (Hodrick-Prescott) trend. One way of estimating the $\boldsymbol{\phi}$ and $\boldsymbol{\mu}$ parameters in (4) is to allow for the first, country-specific term by using the fixedeffects estimator. To get more efficient estimates of spending and revenue equations, we also estimate them jointly with SUR. An alternative way, is to wipe the country-specific intercept out by taking first differences. In this case, we use two different estimators. One is an IV-estimator: we include $\Delta y_{\mathrm{it}-1}$ in the regression and instrument it by $y_{\mathrm{it}-2}$ and $\left(\Delta \mathrm{u}_{\mathrm{t}-1}, \Delta \mathrm{s}_{\mathrm{it}-1}, \Delta \mathrm{x}_{\mathrm{it}-1}\right)$ (plus the corresponding interaction terms). The other is a GLS-estimator: we do not include $\Delta y_{\mathrm{it}-1}$ in the regression, but allow for panel-specific autocorrelation and heteroskedasticity in $\varepsilon_{\text {it. }}{ }^{7}$

The results in Table 4 indicate systematic indirect effects of institutions when it comes to income shocks and lagged policy. (Results for oil prices and population shares are less robust.) The fixed effects (SUR) estimates in columns 1-3 suggest that negative income shocks raise spending as a share of GDP. But this effect is absent, or even overturned, in presidential regimes and under majoritarian elections. These systems are also associated with less inertia in spending, although here the effect of majoritarian elections is weaker. The instrumental variable estimates in column 4 and the GLS estimates in column 5 show that the results for income shocks are very robust, while the results on inertia are a bit less stable.

Persson and Tabellini (2000b) distinguish between positive and negative income shocks. Their preliminary results point towards an asymmetry: in parliamentary and proportional systems negative income shocks significantly raise the spending share, whereas positive income shocks do not lower the spending share. In presidential and majoritarian systems, on the other hand, positive shocks raise

\footnotetext{
${ }^{7}$ It is well-known that the presence of a lagged dependent variable can bias the fixed effects estimator (see e.g, Baltagi, 1995). The problem may be less serious in our panel than in the typical labor context, as the bias diminishes in T and our T is about 40. The IV-estimator we use was suggested by Anderson and Hsiao (1981) and Arrellano and Bond (1991) to correct for the bias in dynamic panels.
} 
spending, whereas negative shocks do nothing. This suggests ratchet effects in the growth of government, but of a very different nature across political systems.

Understanding better the reasons behind the different adjustments to income shocks is an intriguing topic for future theoretical and empirical research.

Electoral cycles Finally, we look for an electoral cycle in total government spending or tax revenue and whether this cycle depends on political institutions. For this purpose, we expand $\mathrm{s}_{\mathrm{it}}$ - the country $i$ variables with institution-specific effects on policy - to also include dummies for election years as well as postelection years. Otherwise, the specification, including all the economic shocks and controls, is the same as in Table 4 (except that the we do not include the oil shocks but instead include a set of common time dummies to allow more precise estimates of the electoral cycle). We also use the same estimation methods.

When the institutional dummies are not included, we find a significant and sizeable post-election cycle in spending, with spending cuts being postponed until after the election. For revenues, we find significant cuts in the election year and (less robust) hikes in the post-election year. These results are remarkable in their own right, as earlier studies have typically not found robust evidence of an electoral cycle in international data, with the exception of the recent study by Shi and Svensson (2000). ${ }^{8}$

As Table 5 reveals, however, these electoral cycles are highly institutiondependent. The post-election cycle - a cut in spending by about 1 percent of GDP and a gain in revenue by 0.5 to 1 percent of GDP - is clearly present only in presidential regimes. The pre-election tax cuts, on the other hand, are visible only in parliamentary regimes. As in the case of the adjustment to income shocks, we do not have a good explanation for these differences.

We have also tried to test the prediction of the career-concern model discussed in Section 2 of a stronger pre-electoral cycle under majoritarian elections. While the signs of the point estimates are consistent with this prediction, their significance is not robust across samples and estimation methods.

\subsection{Composition of government}

Let me turn to the composition of government. Recall that our measures here are central government spending on social security and welfare as a percentage

\footnotetext{
${ }^{8}$ See Alesina, Roubini and Cohen (1997) and Drazen (2000) for surveys of the earlier literature.
} 
of GDP and the ratio of the same variable to spending on goods and services. Persson and Tabellini (2000b) carry out the same battery of tests as those for government size above. Here, I will just give a brief overview of the results.

The cross-sectional results show that broad, non-targeted programs are indeed smaller under majoritarian elections, as predicted by the theory. Ceteris paribus, social security and welfare spending appears to be about 2 percentage points smaller as a share of GDP, and 20-30\% lower as a ratio to spending on goods and services. Statistically, these results are more fragile than the results for overall spending. Qualitatively, they are in line with findings of Milesi-Ferretti et al (2000) for the OECD countries. In this case, however, we find no systematic effect of the regime type.

Unobservable common events are estimated to have a much smaller effect on the spending ratio under majoritarian elections. The cumulative effect on this ratio (from the early 1970s to the 90s) is on the order of $10 \%$. Common events have a smaller effect on social security and welfare in presidential regimes, with a cumulative effect of 4-5 percent of GDP. But the latter result may largely capture the higher overall growth of government in parliamentary regimes.

Observable economic events again trigger institution-specific adjustments. As for aggregate spending, we find negative effects of income shocks on social security and welfare spending. But these effects are significantly smaller, or even nullified, under majoritarian elections and presidential regimes.

For electoral cycles, finally, the findings are quite intriguing. When we do not condition on political institutions, no electoral cycle is observed. But when we do, we find systematic evidence of both pre-election and post-election effects. In connection with a typical election, spending on social security and welfare rises by about 0.2 percent of GDP both before and after the election in countries with proportional elections in parliamentary regimes. Under majoritarian elections in parliamentary countries no effects are visible, however, while in presidential regimes social spending tends to fall by 0.1-0.2 percent of GDP after elections (in consistency with the results for aggregate spending). It is perhaps plausible that we should see spending hikes in parliamentary and proportional systems if politicians in these systems indeed have stronger incentives to rely just on broad programs to get elected or re-elected, as suggested by the theory surveyed in Section 2. A theory of the composition of the electoral cycle under different political institutions has not yet been worked out, however, and constitutes a further challenge for future research. 


\subsection{Corruption}

It is not easy to find empirical counterparts to rent extraction ( $r$ in the simple model) which are comparable across countries. The best proxies are probably those international surveys that try to measure the extent of corruption. I will end by reporting on another ongoing project (Persson, Tabellini and Trebbi, 2000) that relies on such corruption data.

Transparency International conducts a careful survey, including measures of "grand corruption" at the highest levels of government which conforms well with the theoretical models discussed in Section 2. The TPI score runs from 0 (perfectly clean) to 10 (highly corrupt). Unfortunately, these scores are only available annually from the late nineties. Therefore, we must limit our study to cross-country data.

On the other hand, this study includes finer measures of the electoral rule than the single, dichotomous MAJ dummy. Based on the theory, we use two continuous variables. DISMAG measures district size (1 minus the inverse of average district magnitude, in legislative elections). PLIST instead measures the electoral formula, namely the share of legislators elected via party lists (rather than individually). Both measures run between 0 and 1: a score of 0 on both of them corresponds to first past the post in one-member districts, whereas a score of 1 on both corresponds to full proportionality in very large districts.

The intersection of our corruption, electoral and socio-economic data limits the study to at most 82 countries. Some results are shown in Table 6 . The control vector $\mathbf{x}_{\mathrm{b}}$ consists of a dozen economic, social and cultural variables found to correlate closely with corruption in earlier studies (see Persson, Tabellini and Trebbi, 2000). As the first (empty) column shows, these variables explain close to $90 \%$ of the cross-country variance in corruption. Nevertheless, the earlier dichotomous dummies, PRES and MAJ, improve the fit (in terms of adjusted $R^{2}$ ). Both have the negative sign expected from theory, but only $M A J$ is statistically significant. ${ }^{9}$

But this crude measure turns out to mask two effects running in opposite directions. Larger districts - higher DISMAG - lowers corruption, whereas greater use of list voting - higher PLIST - raises it. Both results are consistent with the

\footnotetext{
${ }^{9}$ We also use alternative, non-parametric matching estimators to allow for more flexible functional forms and correct for potential non-random selection (of the electoral rule) on observables (for further discussion see Persson, Tabellini and Trebbi, 2000). The matching estimates largely accord with the regression estimates, suggesting that majoritarian elections indeed have a robust negative effect on corruption.
} 
theory in Section 2: lower barriers to entry (larger districts) decrease corruption, while blunter career concerns (more party list voting) increase it. As columns 3 to 5 demonstrate, these effects are robust to including other institutional variables, namely the legal and colonial origin of countries, earlier empirical studies have found to correlate with corruption (see e.g., Treisman, 2000).

These effects are not only statistically significant, but also quantitatively important. Consider Chile, a country considerably less corrupt than its South American neighbors; its residual from the regression in the first column in Table 6 is about - 2.5, whereas the average South-American country has a residual close to 0 . Our results suggest that between a quarter and a half of this difference might be due to Chile's electoral system, the only one in the region where voters cast their ballots for individual candidates under plurality rule (in two-seat districts).

\section{Final remarks}

Do political institutions shape economic policy? I have argued that this question is theoretically appealing and that posing it offers an attractive opportunity for a convincing application of game theory. I have also reported on ongoing empirical work, which suggests that the answer is a resounding yes.

The results are summarized in Table \%. Empirically, presidential regimes are associated with smaller governments than parliamentary regimes, a smaller and less persistent response of spending to income shocks, a stronger post-election cycle in aggregate spending and revenue, but a weaker cycle in social transfers. Majoritarian elections are associated with smaller broad spending programs than proportional elections and with less corruption; they also have smaller (and perhaps less persistent) spending responses to income shocks, and a weaker election cycle in social transfers. Several of these empirical regularities, those marked with black and bold in Table 7, are in line with the first wave of theory. But others, marked in gray and bold, are still awaiting a theoretical explanation. This is especially so for the results indicating institution-dependent adjustments of policy to economic events and the institution-dependent electoral cycles.

These are promising first steps in a research program. Much work certainly remains, however. So, where might research go next? One direction is clearly to refine the theory of policy. As just noted, our empirical results on policy adjustments and electoral cycles are in search of a theory. To understand them, we need dynamic rather than static models of the relationship between institutions and policy. Dynamic models are also necessary to understand government deficits. 
The results in Persson and Tabellini (2000b) indeed point to systematic differences in deficit behavior across political institutions.

On the policy side, the research so far has concentrated on government spending. It would be interesting - and certainly feasible - to use similar methods in studying other policy instruments, such as the structure of taxation including trade policy. On the institutional side, one should study the effect on policy of more detailed constitutional features; for instance, different types of checks and balances, or different types of confidence requirements.

This suggests another direction, namely refined measurement of political institutions. In some cases this will involve a mere, but time-consuming, compilation of data from existing sources. One example is to trace detailed changes in electoral rules over time; concretely, to compile panel data for variables like DISMAG and PLIST.

In other cases, better measures will require the collection of new primary data. A concrete example is to construct empirical measures of the separations of powers in different political regimes. As this may be a labor-intensive and open-ended task, it is important to use theory as a guide. ${ }^{10}$

Some econometric issues certainly need to be explored in more detail. Even with refined measurement, considerable measurement error will remain in our data. Sharper theory would help in trading off the prospective biases due to measurement and specification errors. Sharper hypotheses, derived from dynamic models, would be especially helpful in avoiding the pitfalls of estimation in dynamic panels.

All in all, a close interplay of theory, measurement and statistical work appears essential for making progress on the broad question I have dealt with in this lecture. I hope some readers will provide some help, both in posing the question more precisely, and in probing the data for an answer.

\footnotetext{
${ }^{10}$ Existing attempts to create such measures can be found in Shugart and Carey (1992) and in Beck et al (2000).
} 


\section{R eferences}

[1] Alesina, A., N. Roubini and G.Cohen (1997), Political Cycles and the Macroeconomy, MIT Press.

[2] Anderson, T. and C. Hsiao (1981), "Estimation of Dynamic Models with Error Components", Journal of the American Statistical Association 76: 598606.

[3] Arrellano, M. and S. Bond (1991), "Some Tests of Specification for Panel Data: Monte Carlo Evidence and an Application to Employment Equations", Review of Economic Studies 58: 277-297.

[4] Austen-Smith, D. and J. Banks (1999), Positive Political Theory I, University of Michigan Press.

[5] Baltagi, B. (1995), Econometric Analysis of Panel Data, Wiley.

[6] Beck, T., G. Clarke, A. Groff, P. Keefer and P. Keefer, "New Tools and Tests in Comparative Politcal Economy: The Database of Political Institutions" mimeo, The World Bank.

[7] Bingham Powell Jr., G. (1982), Contemporary Democracies: Participation, Stability and Violence, Cambridge University Press.

[8] Blanchard, O. and J. Wolfers (2000), "The Role of Shocks and Institutions in the Rise of European Unemployment: The Aggregate Evidence, 1999 Harry Johnson Lecture", Economic Journal 100: C1-33.

[9] Cox, G. (1997), Making Votes Count, Cambridge University Press.

[10] Diermeier, D. and T. Feddersen (1998), "Cohesion in Legislatures and the Vote of Confidence Procedure", American Political Science Review 92: 611621.

[11] Drazen, A. (2000), Political Economy in Macroeconomics, Princeton University Press.

[12] Grossman, G. and E. Helpman (2000), Special-Interest Politics, book manuscript. 
[13] Holmström, B. (1982), "Managerial Incentive Problems - A Dynamic Perspective", in Essays in Economics and Management in Honor of Lars Wahlbeck, Helsinki, Swedish School of Economics.

[14] Inman, R. and D. Rubinfeld (1997), "The Political Economy of Federalism" in Mueller, D. (ed.) Perspectives on Public Choice: A Handbook, Cambridge University Press.

[15] Lijphart, A. (1984), Democracies, Yale University Press.

[16] Lijphart, A. (1999), Patterns of Democracy: Government Forms and Performance in Thirty-Six Countries, Yale University Press.

[17] Lizzeri, A. and N. Persico (2000), "The Provision of Public Goods under Alternative Electoral Incentives", American Economic Review, forthcoming.

[18] Milesi-Ferretti G-M., Perotti, R. and M. Rostagno (2000), "Electoral Systems and the Composition of Public Spending", mimeo, Columbia University.

[19] Mueller, D. ed. (1997), Perspectives on Public Choice: A Handbook, Cambridge University Press.

[20] Myerson, R. (1993), "Effectiveness of Electoral Systems for Reducing Government Corruption: A Game Theoretic Analysis", Games and Economic Behaviour 5, 118-132.

[21] Myerson, R. (1999), "Theoretical Comparison of Electoral Systems: 1998 Schumpeter lecture", European Economic Review 43: 671-697.

[22] Persson, T. Roland, G., and G. Tabellini (1997), "Separation of Powers and Political Accountability", Quarterly Journal of Economics 112, 310-327.

[23] Persson, T. Roland, G., and G. Tabellini (2000), "Comparative Politics and Public Finance", Journal of Political Economy 108: 1121-1161.

[24] Persson, T. and G. Tabellini (1999), "The Size and Scope of Government: Comparative Politics with Rational Politicians, 1998 Alfred Marshall Lecture", European Economic Review 43: 699-735.

[25] Persson, T. and G. Tabellini (2000a), Political Economics: Explaining Economic Policy, MIT Press. 
[26] Persson, T. and G. Tabellini (2000b), "Political Institutions and Economic Policy Outcomes: What Are the Stylized Facts?", mimeo, Institute for International Economic Studies.

[27] Persson, T., Tabellini, G., and F. Trebbi (2000), "Electoral Rules and Corruption", mimeo, Institute for International Economic Studies.

[28] Poterba, J. and J. von Hagen (eds.) (1999), Fiscal Rules and Fiscal Performance, University of Chicago Press.

[29] Shi, M. and J. Svensson (2000), "Conditional Political Business Cycles: Theory and Evidence", mimeo, Institute for International Economic Studies.

[30] Shugart, M. and J. Carey (1992), Presidents and Assemblies: Constutional Design and Electoral Dynamics, Cambridge University Press.

[31] Taagepera, R. and M. Shugart (1989), Seats and Votes: The Effects and Determinants of Electoral Systems, Yale University Press.

[32] Treisman, D. (2000), "The Causes of Corruption: A Cross-National Study", Journal of Public Economics 76: 399-457. 
Figure 1

Size of Government 1960-98

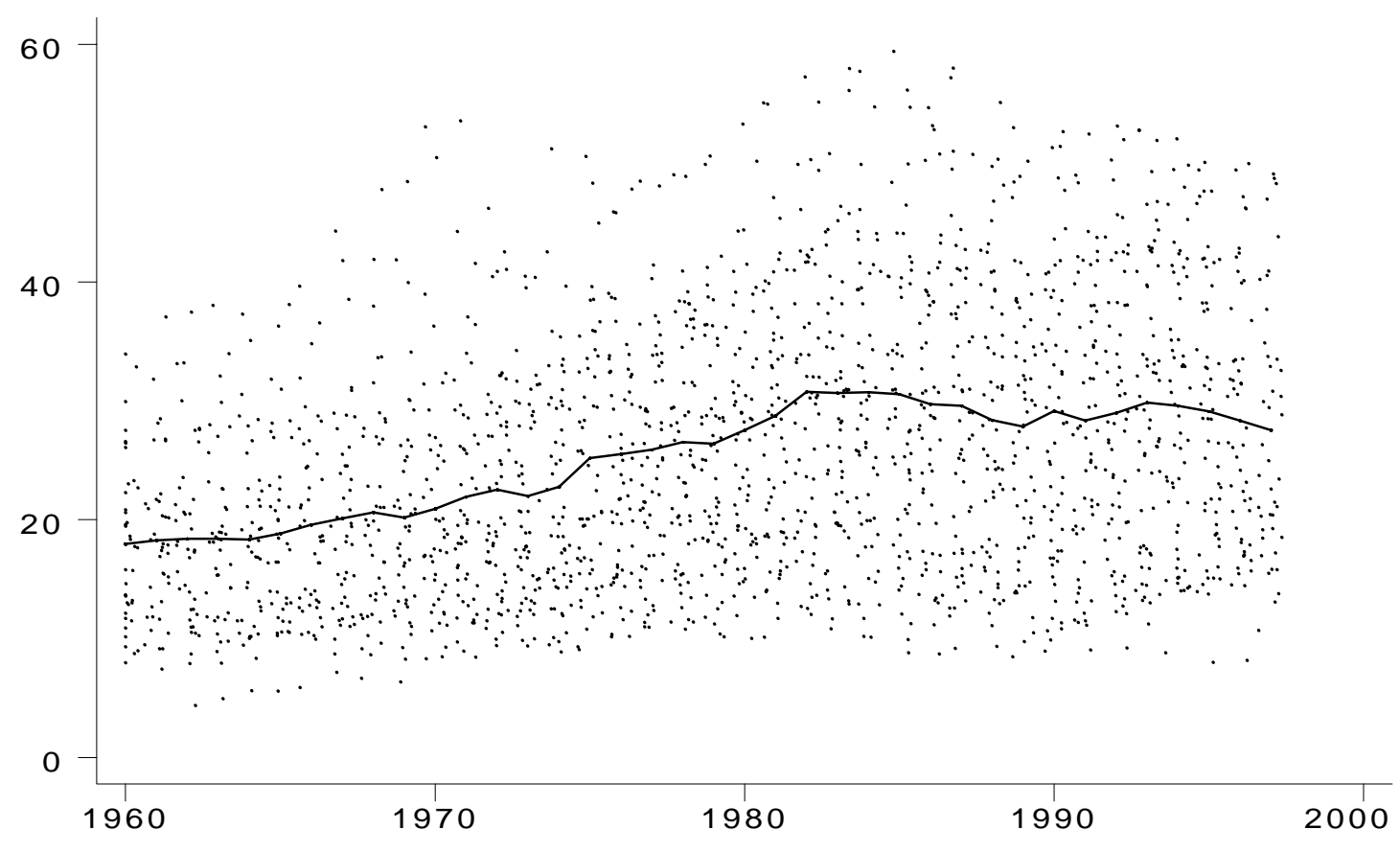




\section{Figure 2}

Political Institutions 1995

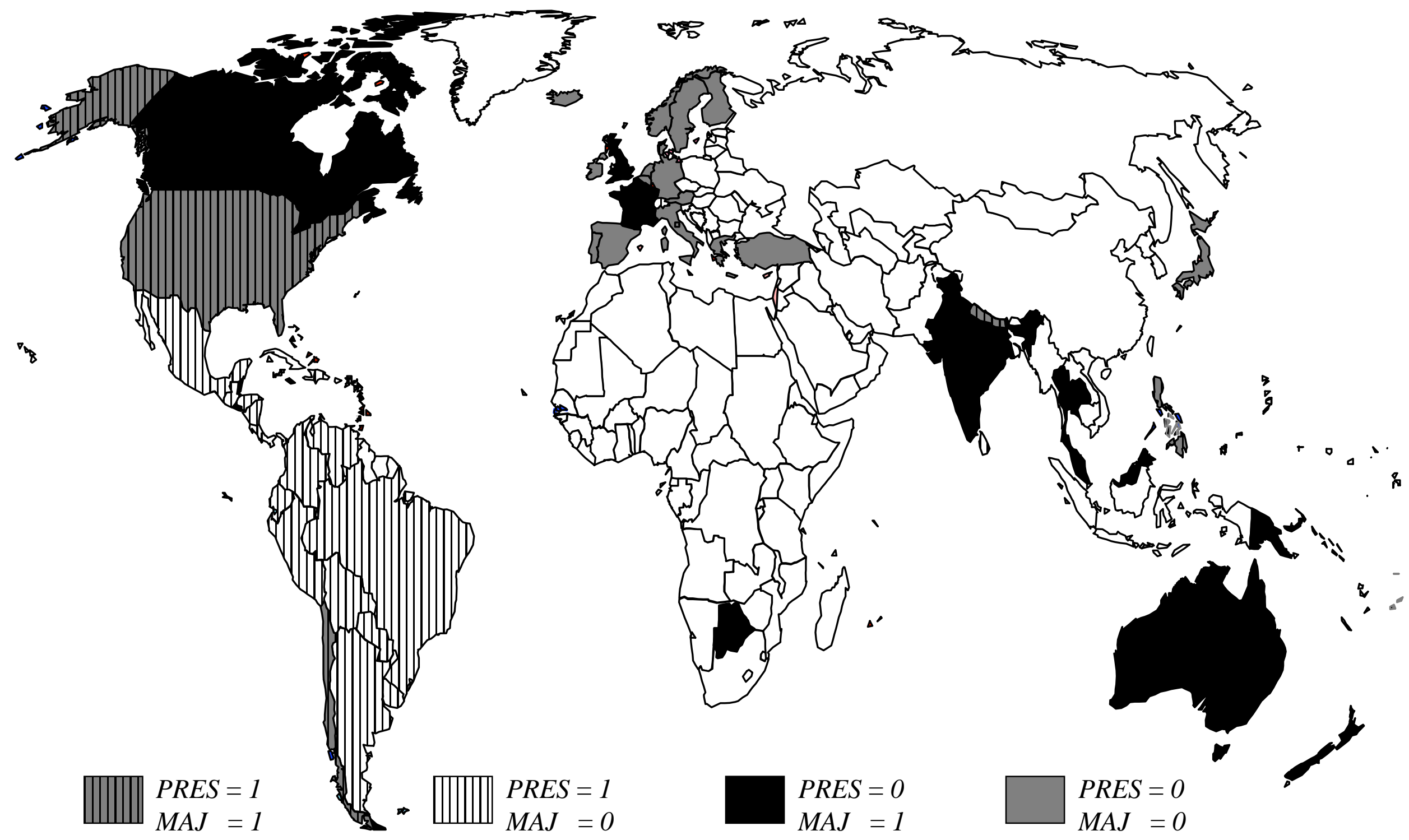


Figure 3

Size of Government 1960-98

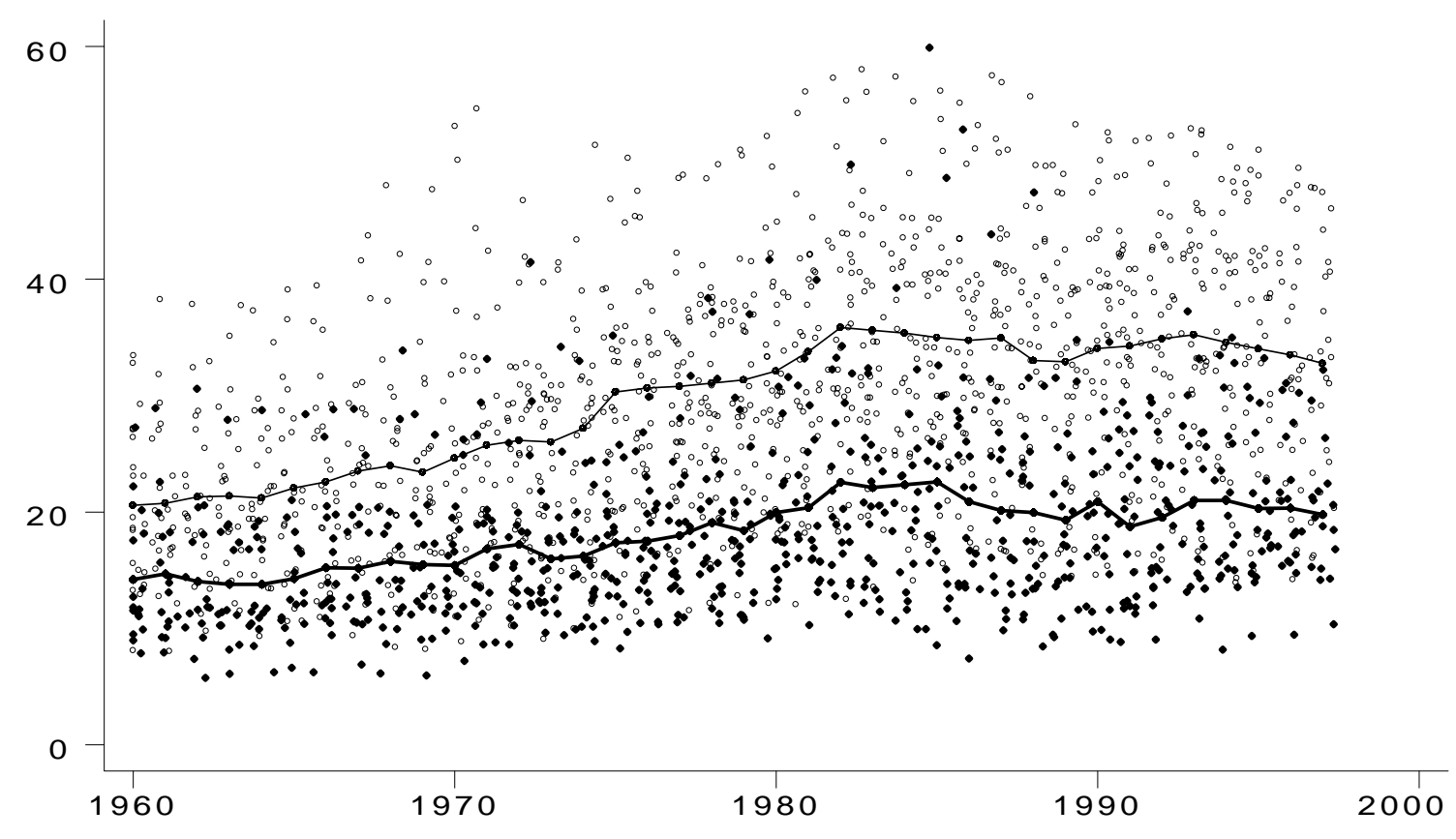


Table 1

Summary of Theory

\begin{tabular}{lcc} 
& PRES (vs. PARL) & MAJ (vs. PR) \\
\hline Size & - & $?$ \\
$\begin{array}{l}\text { Composition } \\
\text { (broad vs. narrow) }\end{array}$ & - & - \\
Rents & - & - \\
\hline Electoral Cycle & NA & + \\
\hline
\end{tabular}




\section{Table 2}

Size of Government

Cross Sections

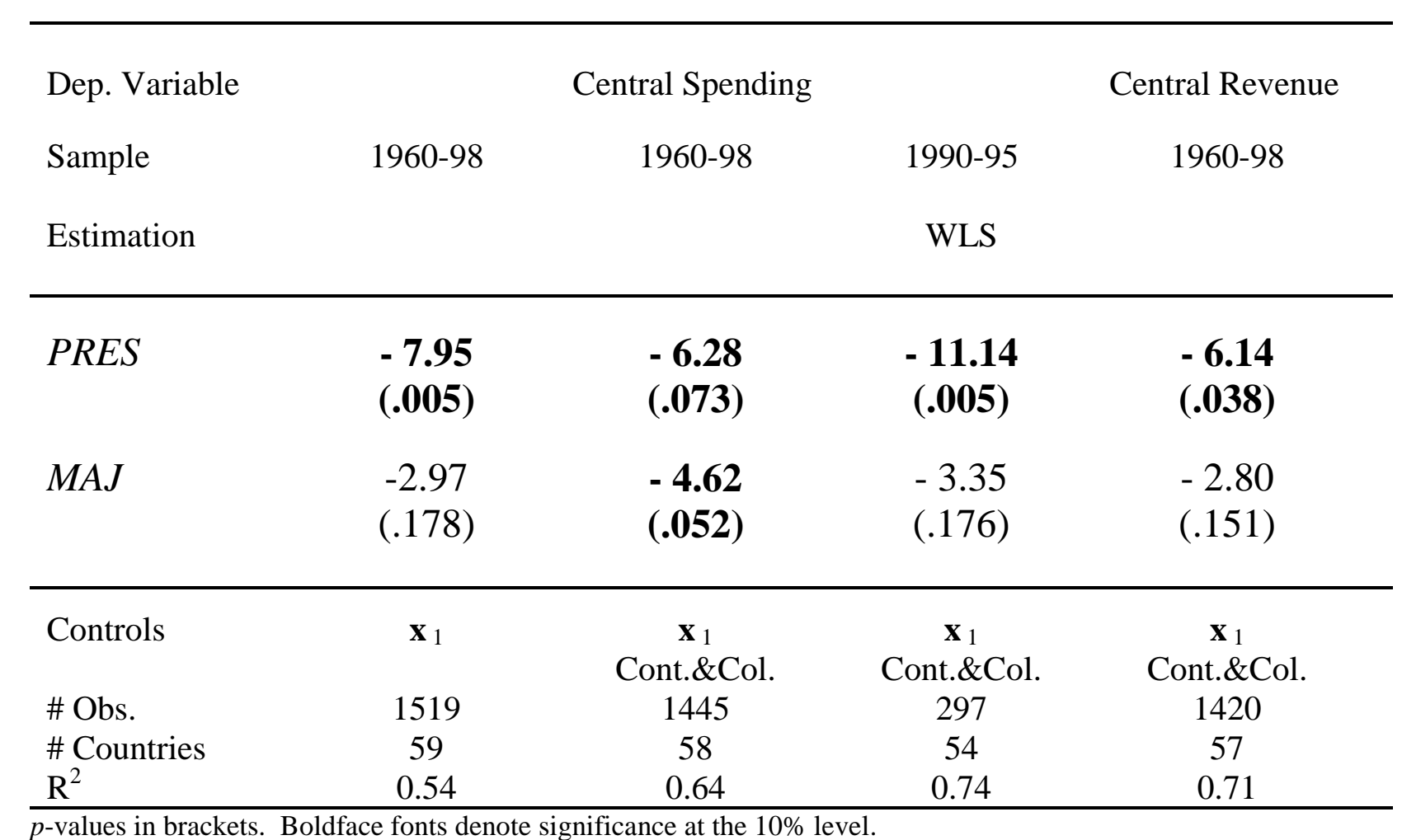

$p$-values in brackets. Boldface fonts denote significance at the $10 \%$ level.

$\mathbf{x}_{1}$ includes controls for income, openness, the population between 15 and 64, and over 65 (see Persson and Tabellini, 2000b).

Cont. and Col. refer to sets of dummies for continents and colonial origin, respectively (see Persson and Tabellini, 2000b). 
Table 3

Size of Government

Unobservable Common Events 1960-98

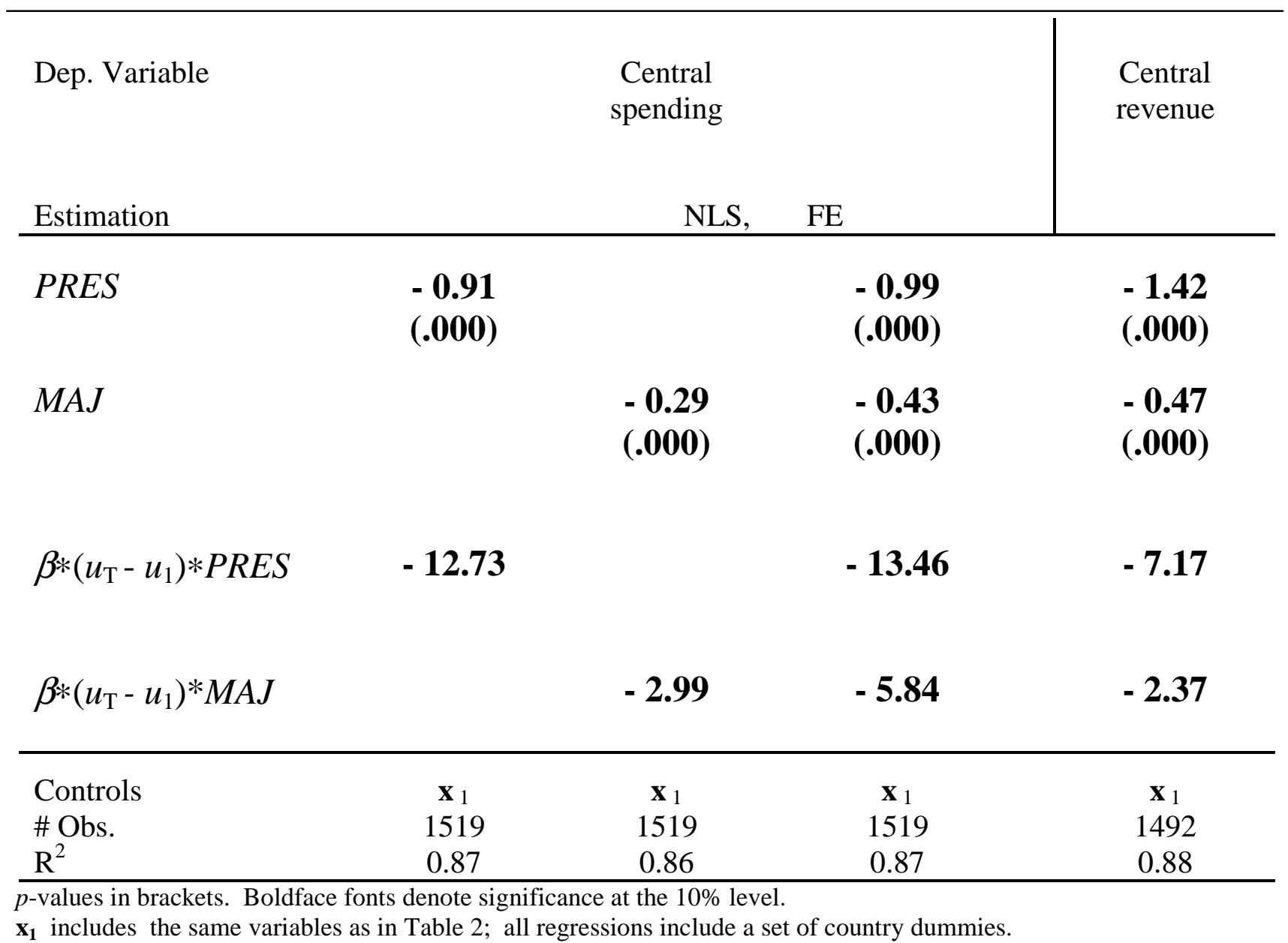




\section{Table 4}

Size of Government

Observable Economic Events 1960-98

\begin{tabular}{|c|c|c|c|c|c|}
\hline Dep. variable & Central & Spending & Revenue & Central & Spending \\
\hline Estimation & $\begin{array}{c}\text { FE } \\
\text { Levels }\end{array}$ & $\begin{array}{c}\text { SUR, FE } \\
\text { Levels. }\end{array}$ & $\begin{array}{c}\text { SUR, FE } \\
\text { Levels }\end{array}$ & $\begin{array}{c}\text { IV } \\
\text { Diffs. }\end{array}$ & $\begin{array}{l}\text { GLS } \\
\text { Diffs. }\end{array}$ \\
\hline$L A G \_S I Z E$ & $\begin{array}{c}\mathbf{0 . 8 4} \\
(.000)\end{array}$ & $\begin{array}{c}0.83 \\
(.000)\end{array}$ & $\begin{array}{c}\mathbf{0 . 8 3} \\
(.000)\end{array}$ & $\begin{array}{c}0.66 \\
(.002)\end{array}$ & \\
\hline$P * L A G \_S I Z E$ & $\begin{array}{l}-0.29 \\
(.000)\end{array}$ & $\begin{array}{r}-0.28 \\
(.000)\end{array}$ & $\begin{array}{l}-0.25 \\
(.000)\end{array}$ & $\begin{array}{l}-0.35 \\
(.318)\end{array}$ & \\
\hline$M * L A G \_S I Z E$ & $\begin{array}{l}-0.05 \\
(.073)\end{array}$ & $\begin{array}{l}-0.04 \\
(.115)\end{array}$ & $\begin{array}{l}-0.04 \\
(.040)\end{array}$ & $\begin{array}{l}-0.12 \\
(.804)\end{array}$ & \\
\hline YSHOCK & $\begin{array}{l}-0.19 \\
(.000)\end{array}$ & $\begin{array}{l}-0.19 \\
(.000)\end{array}$ & $\begin{array}{l}-0.07 \\
(.092)\end{array}$ & $\begin{array}{r}-0.24 \\
(.002)\end{array}$ & $\begin{array}{r}-0.23 \\
(.000)\end{array}$ \\
\hline$P * Y S H O C K$ & $\begin{array}{c}0.27 \\
(.000)\end{array}$ & $\begin{array}{c}0.29 \\
(.000)\end{array}$ & $\begin{array}{c}0.10 \\
(.058)\end{array}$ & $\begin{array}{c}0.32 \\
(.000)\end{array}$ & $\begin{array}{c}0.30 \\
(.000)\end{array}$ \\
\hline$M * Y S H O C K$ & $\begin{array}{c}0.23 \\
(.000)\end{array}$ & $\begin{array}{c}0.23 \\
(.000)\end{array}$ & $\begin{array}{c}0.11 \\
(.020)\end{array}$ & $\begin{array}{c}0.22 \\
(.001)\end{array}$ & $\begin{array}{c}0.12 \\
(.001)\end{array}$ \\
\hline $\begin{array}{l}\text { Controls } \\
\text { \# Obs. } \\
\mathrm{R}^{2} \\
\end{array}$ & $\begin{array}{c}\mathbf{x}_{2} \\
1475 \\
0.81 \\
\end{array}$ & $\begin{array}{c}\mathbf{x}_{2} \\
1432 \\
0.95 \\
\end{array}$ & $\begin{array}{c}\mathbf{x}_{2} \\
1432 \\
0.96 \\
\end{array}$ & $\begin{array}{c}\mathbf{x}_{2} \\
1421\end{array}$ & $\begin{array}{c}\mathbf{x}_{2} \\
1472\end{array}$ \\
\hline
\end{tabular}


Table 5

Size of Government

\section{Electoral Cycles 1960-95}

\begin{tabular}{|c|c|c|c|c|}
\hline $\begin{array}{l}\text { Dep. Variable } \\
\text { Estimation }\end{array}$ & $\begin{array}{l}\text { Central } \\
\text { FE, SUR } \\
\text { Levels } \\
\end{array}$ & $\begin{array}{c}\text { Spending } \\
\text { IV } \\
\text { Diffs. } \\
\end{array}$ & $\begin{array}{l}\text { Central } \\
\text { FE, SUR } \\
\text { Levels } \\
\end{array}$ & $\begin{array}{c}\text { Revenue } \\
\text { IV } \\
\text { Diffs. } \\
\end{array}$ \\
\hline$P R E S * E L_{t}$ & $\begin{array}{c}0.10 \\
(.784)\end{array}$ & $\begin{array}{l}-0.15 \\
(.710)\end{array}$ & $\begin{array}{l}-0.31 \\
(.328)\end{array}$ & $\begin{array}{l}-0.47 \\
(.297)\end{array}$ \\
\hline$P R E S * E L_{t-1}$ & $\begin{array}{l}-0.80 \\
(.031)\end{array}$ & $\begin{array}{l}-1.02 \\
(.017)\end{array}$ & $\begin{array}{c}0.52 \\
(.095)\end{array}$ & $\begin{array}{c}0.87 \\
(.013)\end{array}$ \\
\hline$P A R L * E L_{t}$ & $\begin{array}{l}-0.03 \\
(.899)\end{array}$ & $\begin{array}{l}-0.27 \\
(.261)\end{array}$ & $\begin{array}{l}-0.31 \\
(.066)\end{array}$ & $\begin{array}{l}-0.45 \\
(.026)\end{array}$ \\
\hline$P A R L * E L_{t-1}$ & $\begin{array}{l}-0.11 \\
(.565) \\
\end{array}$ & $\begin{array}{l}-0.22 \\
(.373)\end{array}$ & $\begin{array}{c}0.15 \\
(.366)\end{array}$ & $\begin{array}{c}0.31 \\
(.129)\end{array}$ \\
\hline $\begin{array}{l}\text { Controls } \\
\text { \# Obs. } \\
\mathrm{R}^{2}\end{array}$ & $\begin{array}{c}\mathbf{x}_{3} \\
1350 \\
0.95\end{array}$ & $\begin{array}{c}\mathbf{x}_{3} \\
1339\end{array}$ & $\begin{array}{c}\mathbf{x}_{4} \\
1350 \\
0.96\end{array}$ & $\begin{array}{c}\mathbf{x}_{4} \\
1316\end{array}$ \\
\hline
\end{tabular}


Table 6

Corruption

Cross sections

Dep. variable

TPI-scores 1996-98

Estimation

WLS

\begin{tabular}{|c|c|c|c|c|c|}
\hline PRES & & $\begin{array}{l}-0.30 \\
(.369)\end{array}$ & & & \\
\hline$M A J$ & & $\begin{array}{l}-0.61 \\
(.015)\end{array}$ & & & \\
\hline PLIST & & & $\begin{array}{c}1.48 \\
(.010)\end{array}$ & $\begin{array}{c}1.51 \\
(.009)\end{array}$ & $\begin{array}{c}1.40 \\
(.021)\end{array}$ \\
\hline$D I S M A G$ & & & $\begin{array}{l}-1.09 \\
(.101)\end{array}$ & $\begin{array}{l}-1.47 \\
(.034)\end{array}$ & $\begin{array}{r}-1.40 \\
(.041)\end{array}$ \\
\hline Controls & $\mathbf{x}_{\mathrm{b}}$ & $\mathbf{x}_{\mathrm{b}}$ & $\mathbf{x}_{\mathrm{b}}$ & $\begin{array}{l}\mathbf{x}_{\mathrm{b}} \\
\text { Leg. }\end{array}$ & $\begin{array}{c}\mathbf{x}_{\mathrm{b}} \\
\text { Leg. \& Col. }\end{array}$ \\
\hline $\begin{array}{l}\text { \# Obs. } \\
R^{2}\end{array}$ & $\begin{array}{c}82 \\
0.88\end{array}$ & $\begin{array}{c}81 \\
0.90\end{array}$ & $\begin{array}{c}80 \\
091\end{array}$ & $\begin{array}{c}80 \\
092\end{array}$ & 80 \\
\hline
\end{tabular}

$p$-values in brackets. Boldface fonts denote significance at the $10 \%$ level.

$\mathbf{x}_{\mathrm{b}}$ includes a set of 12 socio-economic variables; Leg. and Col. denote sets of dummies for

legal and colonial origin, respectively (see Persson, Tabellini and Trebbi, 2000) 
Table 7

Summary of Results

\begin{tabular}{lcccc}
\hline & \multicolumn{2}{c}{$P R E S($ vs. $P A R L)$} & \multicolumn{2}{c}{$M A J($ vs. $P R)$} \\
& Evidence & Theory & Evidence & Theory \\
\hline $\begin{array}{l}\text { Size } \\
\begin{array}{l}\text { Composition } \\
\text { (broad vs. narrow })\end{array}\end{array}$ & - & - & 0 & $?$ \\
$\begin{array}{l}\text { Rents } \\
\text { Electoral Cycle }\end{array}$ & 0 & - & - & - \\
$\begin{array}{l}\text { Adjustment to } \\
\text { events }\end{array}$ & $+/-$ & NA & 0 & - \\
\hline
\end{tabular}

